\title{
The Effect of Grammar Consciousness-Raising Tasks on EFL Learners' Reading Comprehension and Writing Ability
}

\author{
${ }^{1}$ Mania Nosratinia, ${ }^{2}$ Somayeh Roustayi \\ ${ }^{1}$ Assistant Professor of Applied Linguistics, Islamic Azad University, at Central Tehran, Iran \\ ${ }^{2} M A$ in TEFL, Islamic Azad University, at Central Tehran, Iran
}

\begin{abstract}
The focus of this study is to investigate the effect of grammatical consciousness-raising tasks on EFL learners' reading comprehension and writing ability. The participants were 60 female intermediate EFL learners with age range of 20-35 who were divided into two groups of control and experimental after being homogenized by a piloted PET test and two piloted researchers-made reading comprehension and writing ability tests. After the treatment phase, the piloted researchers-made reading comprehension and writing ability post-tests were administered. To investigate the two research questions of the study, two independent t-tests were conducted. Also, the inter-rater reliability for the pretest and post-test of writing was calculated through Cornbach's Alpha. The obtained results revealed that the improvement occurred in the reading comprehension and writing ability of the participants of experimental group, in comparison to their previous stage, was due to the introduction of a specific variable which was the technique of grammar consciousness-raising tasks. Furthermore, the results revealed that grammar consciousness-raising tasks result in a better performance on writing than reading comprehension.
\end{abstract}

Key words: teaching grammar, consciousness-raising tasks, reading comprehension, writing ability

\section{Introduction}

Language is an effective tool used in everyday communication. Grammar constitutes a crucial concept of the language and it is a device for constructing and expressing meaning without which, effective communication would be impossible (Crivos \& Luchini, 2012).

The effectiveness of teaching grammar and the necessity of learning grammar for L2 learners is now a well-established fact in Second Language Acquisition (Borg \& Burns, Celce-Murcia, Cullen, Davies, Ellis, Fotos, Sheen, as cited in Abbasian Boroujeni, 2012) which has led to reconsideration of the role of grammar in L2 classroom.

Despite such empirical support for learning and grammar instruction, however, over the previous century the question of whether to teach grammar or not has been contentious. The many answers to this question form a spectrum with two opposite ends. At one end are highly implicit approaches to grammar teaching, and at the other end are those explicit approaches that are in favor of grammar instruction (Rodríguez, 2009). Explicit grammar instruction refers to those instructional strategies used to raise learners' conscious awareness of the form or structure of the target language. Through explicit instruction learners are able to notice features in the input data. Implicit knowledge, on the other hand, is a non-conscious and automatic abstraction of the structural nature of the material arrived at from experience of instances (Ellis, 2005).

Contemporary research on the merits of the implicit and explicit approaches has led to the consensus that an exclusive emphasis on either extreme impedes learners' acquisition of language (Green \& Hecht, Long, Norris \& Ortega, as cited in Rodriguez, 2009). Therefore, the heated debate has revolved over the question of how to teach grammar rather on whether grammatical competence is important. In other words, the challenge is "to find ways of developing the required grammatical accuracy and the ability to communicate at the same time, without sacrificing one or the other" (Behrouzi \& Kazemirad, 2012).

Current grammar pedagogy in English Language Teaching (ELT) foster consciousness-raising (CR) approaches (Batstone, Celce-Murcia, Thornbury, as cited in Nitta \& Gardner, 2009). Consciousness-raising is a cognitive approach to grammatical instruction developed by Sharwood-Smith (as cited in Walsh, 2005). It is a learner-centered orientation, with emphasis on learning processes and strategies where the learners rely on their intellectual capacities and use their cognitive modes to learning. Richards and Schmidt (2002) defined consciousness-raising as:

...techniques that encourage learners to pay attention to language form in the belief that an awareness of form will contribute indirectly to language acquisition. Techniques include having students infer grammatical rules from examples, compare differences between two or more different ways of saying something, observe differences between a learner's use of a grammar item and its use by native speakers. A consciousness-raising approach is contrasted with traditional approaches to the teaching of grammar (e.g. 
drilling, sentence practice, sentence combining), in which the goal is to establish a rule or instill a grammatical pattern directly. (p. 109)

Consciousness-raising approach helps the learner to draw attention receptively to formal and semantic features of linguistic forms, with the goal of implicit knowledge for the learner that includes inductive learning, and makes no promises about when or where students will master the content (Ellis, 2003). In other words, this approach provides learners with successful acquisition and enables them to use the language.

It is possible way to integrate the teaching of grammar with opportunities for communication and exchange of information in grammar tasks. As Ellis (2003) claims, a consciousness-raising task engages learners in thinking and communicating about language. Thus, a language point becomes the topic that is talked about. Consciousness-raising tasks are communicative tasks in which learners, using the target language, discuss the meanings of various grammatical forms and try to identify regular patterns in their use. The learners are not required to produce or practice the forms. Rather, the content of the communicative task is grammar. They develop grammatical knowledge while they are communicating (Fotos, 1994).

Grammar consciousness-raising tasks combine the development of knowledge about problematic L2 grammatical features with the provision for meaning-focused use of the target language. However, for this task type to be pedagogically useful in ESL/EFL classrooms, it must be shown that task performance is as effective as a teacher-fronted grammar lesson in promoting gains in knowledge of the target structure and is comparable to performance of regular communicative tasks in terms of opportunities for communicative language exchange.

Even though grammatical competence is presumed to be indispensable for identifying syntactic relations of sentence components, there has been little research on how readers' knowledge of grammar contributes to L2 reading comprehension (Alderson, Shiotsu \& Weir, Urquhart \& Weir, as cited in Grabe, 2008).

Current theories on reading comprehension generally involve conceptual representations with several mutually constraining layers. There are typically a local-level representation (i.e., text-model) based on textbased information and a global-level representation (i.e., situation-model) where the content of the text becomes integrated into the reader's larger conceptual structure (Kintsch, 1988; Kintsch \& Van Dijk, 1978). Throughout the construction of these different levels of semantic structures, the reader's knowledge of grammar constrains the entire reading process. More specifically, parsing process guided by grammar operates on locally assembled text segments, and thus global text comprehension can be severely impaired if readers generate inaccurate and/or incomplete local text representation (Koda, 2007). Hence, even though reading comprehension is mostly conceptual, it still is affected by the knowledge of grammar either directly or indirectly.

When the issue turns to second language (L2) reading, the role of grammar becomes more complex. For one, L2 reading differs from L1 reading in that L2 readers "start to read in the second language before achieving the kind of grammatical maturity and the level of oral vocabulary that L1 readers attain before they begin to read" (Shiotsu, 2009, p. 16). Thus, L2 learners must learn how phrases are constructed and cases are assigned to the constructed phrases in a new language (Koda, 2007).

However, the role of grammar in $\mathrm{L} 2$ reading has not received much attention by researchers (Alderson, Nassaji, Shiotsu \& Weir, Urquhart \& Weir, as cited in Grabe, 2008). On the one hand, this may be attributable to the very nature of reading as a receptive language skill for comprehending the messages of the texts. Thus, knowledge of structure was regarded to have less to do with comprehending a text than levels of other components such as vocabulary, background knowledge, and reading strategies. On the other hand, the 30-year long dominance of Communicative Language Teaching (CLT) that puts a near-exclusive emphasis on macrolanguage skills and communicative functions has somewhat downgraded the need to address the issue of the role of grammar in L2 reading (Han \& D'Angelo, Urquhart \& Weir, as cited in Grabe, 2008). Briefly, the role of grammar in understanding is not recognized (Grabe, 2008). Despite doubts cast over the role of grammar knowledge in reading comprehension, there are compelling reasons to consider this issue (Nagy, Nation, as cited in Grabe, 2008).

Moreover, reading is an active, fluent process which involves the reader and the reading materials in building meaning. Meaning does not reside on the printed page, nor is it only in the reader (Anderson, as cited in Ueta, 2005). A reader needs at least six types of knowledge to make sense of a text: genre knowledge, topic knowledge, sociocultural knowledge, general world knowledge, morphological knowledge, and syntactic knowledge (Hedge, 2003). Syntactic knowledge or sentence-structure knowledge helps a reader to see relations between ideas, including relationships between main ideas and details and also relations among each part of the components of a sentence in order to have a better analysis of the text and sentences, and hence a better understanding of them.

Consciousness-raising tasks constitute a form of discovery learning in reading (Weisi, 2012). It helps learners to discover syntactic relations among the words and to find how they are supposed to be understood in each context. This enables learners to take in and store words together so that basic grammatical information can be extracted to support clause level meaning (Lopez, 2008). 
In addition to be effective readers, L2 learners need guidance to become effective writers (Chin, 2000). A good essay is characterized by unity, by which we mean relevance of ideas to the topic; coherence, the continuity and link between the paragraphs and between sentences; and completeness, which refers to the conclusive development of a point either in the paragraph or in the essay. Of the above three points, coherence can hardly be taught or achieved without some knowledge of grammar. This means that in order to communicate successfully in written form, learners need grammatical knowledge of concepts to put their ideas into intelligible sentences and teachers should focus on the grammatical concepts that are essential for the clear communication of meaning.

As Lin (cited in Riyad Sharaf, 2011) stated, without grammar, people would have only individual words or sounds, pictures, and body language to communicate meaning. Moreover, effective grammar can help students use this knowledge as they write.

As a way of teaching grammar, CR tries to provide a language environment for learners to discover grammatical features on their own in order to develop their capability in writing. CR tasks are set in the same purpose with the process approach to writing (Sharil, 2009).

The put forward points give ample justification for witnessing a growing body of research in our field that aims at conducting further investigation into the nature of grammar consciousness-raising tasks and its effects on different skills and sub-skills of language. So, the present study tried to investigate the effect of grammar consciousness-raising tasks on EFL learners' reading comprehension and writing ability. To fulfill the objective of the study, the following research questions were proposed:

1. Do teaching grammatical consciousness-raising tasks have any statistically significant impact on EFL learners' reading comprehension?

2. Do teaching grammatical consciousness-raising tasks have any statistically significant impact on EFL learners' writing ability?

\section{Participants}

\section{Method}

To accomplish the objectives of this study, 60 female intermediate level students with age range of 2035 who were learning English as a foreign language were non-randomly selected from intermediate level classes at Nashr Language School in Malayer, Iran. The participants were homogenized by a sample Preliminary English Test (PET) and a reading comprehension and writing ability pretests containing the grammatical features that were the focus of the study at the beginning of the term.

After homogenizing, the participants were randomly assigned into two experimental groups and two control groups each containing 15 students, making 30 students serves as experimental group and 30 as control group.

Besides, to ensure the reliability of the research instruments, 30 other students, at Nashr language school, who had almost the same characteristics as the main sample of the study, took part in piloting the PET proficiency test, reading comprehension and writing ability pre and post-tests.

Also, two raters (one of the researchers and another qualified rater) attended in the assessment of writing and speaking sections of PET and writing pretest and post-tests.

\section{Language Proficiency Test}

\section{Instrumentation}

In order to homogenize the language proficiency of the students, the PET proficiency test (Preliminary English Test) which was developed in 2004 was administered. PET is one of the standardized tests among the series by Cambridge ESOL. It is an exam for people who can use every day written and spoken English at an Intermediate level. It tests four skills of reading, writing, listening, and speaking.

\section{Writing Rating Scale of PET}

The rating scale used to rate the writing section of PET in this study was the one provided by Cambridge under the name of General Mark Schemes for Writing. The rating was done on the basis of the criteria stated in the rating scale including the rating scale of $0-5$.

\section{Speaking Rating Scale of PET}

The rating scale used to rate the oral proficiency of the subjects was the predetermined official Cambridge General Mark Schemes for speaking. The rating was done on the basis of the criteria stated in the rating scale including the range of scores from 0 to 5 . 


\section{Reading Comprehension \& Writing Ability Pretests}

A piloted researchers-made reading and writing pretests containing the grammatical features that were the focus of the study were administered to ensure both the homogeneity of the participants regarding their reading comprehension and writing ability and their lack of knowledge on the target grammatical features.

The reading comprehension pretest includes two reading passages each followed by 8 True/False items making the total number of 16 items lasting for 20 minutes. The passages were selected from quizzes for units 10 and 12 in Touch Stone Book 2, teacher`s edition (McCarthy, McCarten, Sandiford, 2005). The writing ability pretest comprised two writing tasks each lasting for 40 minutes.

\section{Reading Comprehension \& Writing Ability Post-tests}

A piloted researchers-made reading and writing post-tests were designed based on the topics of the course book which were the focus of the study and administered at the end of the treatment to measure the learners' reading comprehension and writing ability in both control and experimental groups. The reading comprehension post-test comprises two reading passages which were selected from Touch Stone Book 2 (McCarthy et al., 2005), units 10 and 12 and each followed by 7 and 9 True/False items making the total number of 16 items. The allocated time was 20 minutes.

The writing ability post-test was administered at the end of the treatment and includes two writing tasks that candidates should do each of them in 40 minutes.

\section{Rating Scale for Writing Pre and Post-tests}

The rating scale which was used for the purpose of rating the participants' writing ability in this study for both writing pre and post-tests was an analytic writing rating scale by Weir (as cited in Cushing Weigle, 2002) comprising seven aspects of writing including relevance, adequacy of content, cohesion, compositional organization, adequacy of vocabulary for purpose, grammar, mechanical accuracy (including punctuation and spelling). The band scores for each of these aspects of writing is $0-3$.

\section{Material}

The text book which is used in this research is "Touch stone 2", by Michael McCarthy, Jeanne MacCarten, and Helen Sandiford (2005) which consists of 12 units. The main purpose of this book is to integrate listening, speaking, reading, writing, grammar, vocabulary, and pronunciation. This book is taught in three 4-unit sections in 20 sessions and one more session for the final test in Nashr Language School. For the purpose of this study, students dealt with 2 units of the third part of the book (units 10 and 12) that were designed in terms of grammatical consciousness-raising tasks. The grammatical points that were covered in these units were as follows: comparative and superlative adjectives, nouns, verbs tenses mostly future with may/might, will, be going to, and present continuous.

\section{Consciousness- Raising Tasks}

These tasks were developed by the researchers based on consciousness-raising sequences presented in "Consciousness-raising Activities" (Willis \& Willis, 1996) and "The Effect of Consciousness-raising Tasks on Iranian Elementary EFL Learners' Syntax Acquisition" (Behrouzi \& Kazemirad , 2012) in which the sequence of the tasks are as follows:

1. Attention: Students are given a text containing enough examples of the target structure to process it for meaning.

2. Noticing: The target structure is highlighted through underlining and italicizing. Students are asked to identify the grammatical sentences from the ungrammatical ones \& fill in the blanks with the target structure.

3. Analysis: Students look at the examples in the texts and discover how the target structure work. They are asked to formulate and present a rule for what they have found.

4. Checking: Students do an activity to check whether they understood how to use the aimed structure.

5. Production: Students are given the opportunity to try out the target structure by producing their own sentences or phrases to complete a text.

The texts were selected from two surveys from Touch Stone Book 2 (McCarthy et al., 2005) that contained the correct usage of the target features. The sentences with the target feature were underlined and italicized to attract the learners' attention.

\section{Procedure}

To accomplish the purpose of the study the following procedure was pursued:

Prior to the treatment, the PET test, the researchers-made reading comprehension and writing pretest and posttests were standardized by piloting them among a group of 30 female students with almost similar 
characteristics of the representative sample in three different sessions. Then the three characteristics of individual items (Item Facility, Item Discrimination, and Choice Distribution) were calculated in order to omit the malfunctioning items. The Cronbach's alpha formula was employed for calculating the reliability of the tests' scores gained by the participants.

The writing part was rated according to the rating scale provided by Cambridge for PET by one of the researchers and another qualified rater. First of all, the rating scale was shared between the two raters and then in order to make sure that both had the same understanding of it, a few papers were rated by both. Since it was shown that there was consistency between the papers they rated, the researcher moved to the actual practice. Later on, the inter-rater reliability was calculated on the basis of the ratings done by both raters for the pilot test of PET. Since there was an acceptable consistency between the two raters, the researcher went through the same procedure for the main participants.

Also, the speaking part of PET was rated according to the rating scale provided by Cambridge General Mark Schemes for speaking following the same procedure for correcting writings.

An already piloted PET was given to 110 intermediate level students of Nashr Language School who were selected non-randomly and 80 students whose score fall between one standard deviation above and below the mean were chosen.

To make sure that the students were not significantly different in terms of their reading comprehension \& writing ability (the dependent variables of the study), and also they do not have prior knowledge about the target grammatical features, they were given a reading comprehension pretest followed by a writing ability pretest.

The rating scale which was used for the purpose of rating the participants' writing for both writing pre and post-tests is an analytic writing rating scale by Weir (as cited in Cushing Weigle, 2002). The same procedure for correcting PET writing section was also used for this purpose.

Thus, 60 participants whom obtain scores within the range of one standard deviation above and below the mean were selected for the purpose of the study.

The 60 subjects were divided randomly into two groups: one experimental and one control. Since 30 is too large a number for the students in one class (due to the fact that classes with more than 15 students are not allowed in Nashr Language School), two classes of 15 and 15 for each group was used, that is, two classes of 15 as the experimental group and two classes of 15 as the control group.

All the participants were taught using the same material and they received the same amount of instruction. All four classes comprising the two groups were instructed by the same teacher (one of the researchers). The course consisted of 10 sessions of 90 minutes spanning over a period of approximately five weeks.

\section{Control group}

The control group went under the normal instruction and receives a formal, teacher-fronted grammar lesson in that the teacher gave instruction about the grammatical points. The participants were taught units 10 and 12 of "Touch Stone Book 2". The participants read texts containing the aimed structure which were not bolded, underlined or used any other techniques to attract the learners' attention. The teacher asked them some questions about the text. Then, they checked whether the sentences after the text were true or false and compared their answers in pairs. The teacher gave them the correct answers. The students were given some incomplete sentences and were asked to fill the blanks. Then, they work in pairs to check their answers. After that, they looked at the sentences in first part and tried to correct the wrong sentences.

They worked in pairs and discussed why they are wrong. Afterwards, the correct forms and the reasons were presented by the teacher through explaining the structure and providing the learners with a table summarizing the uses of that structure. Then, they did two activities of sentence making and completing a text relating to the aimed structure.

\section{Experimental group}

The experimental group was instructed through consciousness-raising (CR) tasks which are supposed to help them raise their consciousness while learning the grammatical points.

For the treatment phase, two lessons (lessons 10 and 12) of "Touch Stone Book 2" were chosen as to direct the learners' attention to the form of the grammatical points. The researchers provided two lessons based on the rules of consciousness-raising tasks. Each of the lessons consisted of special tasks through which the learners become conscience about the grammatical points.

First, the teacher asked students to read texts containing the aimed grammatical structure and asked them some related questions. The students were given the same texts containing the target grammatical points that were emphasized by using the technique of underlining, and italicizing to draw learners' attention. They were asked to identify the ungrammatical sentences from grammatical ones and check their answers in pairs. 
Then, the teacher provided the answers. After that, some fill in the blank exercises were given to students to complete them with the targeted structures and compare them in pairs. Next, they look back to the first part and try to correct the false sentences by reading the text again. The learners worked in pairs, trying to discuss why they are wrong. They were given enough time to make up rules and explain how and when the target structure is used. The teacher asked each student to read aloud her rule and she wrote the correct ones on the board trying to make a chart to summarize the uses of the structure.

During this phase the teacher did not give any explicit explanation. She asked the students how to draw and complete the chart. The rule-confirmation process was: using of interjections and writing the correct ones where the students said. The students received some phrases or expressions to make sentences with them by using the aimed structures. They also worked in pairs comparing their answers. Then, the teacher provided the correct forms. During task performance in both experimental and control groups, the participants were given time to negotiate and do the tasks in pairs.

At the end of the treatment phase, both experimental and control groups received a piloted researchersmade reading comprehension and writing ability post-tests. Then, two groups' writing samples were scored by two raters (one of the researchers and another qualified rater) using the Weir rating scale (as cited in Cushing Weigle, 2002). Some sample writings were rated by the two raters to reach the same understanding on the selected analytic rating scale and therefore to improve the overall reliability between the two raters.

The obtained data comprises of the participants' scores on the PET, to make sure the participants are at the same proficiency level; the scores of the participants on the reading comprehension and writing pretests, to ensure their homogeneity in reading comprehension and writing ability; and their scores on the reading comprehension and writing ability post-tests, to assess the effect of grammatical consciousness raising tasks on the reading comprehension and writing ability of experimental group were analyzed using different descriptive and inferential statistics.

\section{Results}

\section{Descriptive Statistics of the PET Proficiency Test, Piloting}

The PET consisted of 67 items including three sections of reading (35 items), writing ( 7 items), listening (25 items) and also another section for speaking. The test was administered to a group of 30 intermediate-level EFL learners at the same language school bearing almost the same characteristics as the target sample. All items went through an item analysis procedure and four items were discarded due to their malfunctioning characteristics.

Following the piloting of the test, the mean and standard deviation of the raw scores and the reliability were calculated. The mean and the standard deviation of this administration were found to be 75.60 and 9.17 respectively. Table 1 shows the descriptive statistics of the PET in the pilot phase.

Table 1- Descriptive Statistics of the PET, Piloting

\begin{tabular}{|l|r|r|r|r|r|r|}
\hline & N & Minimum & Maximum & \multicolumn{1}{c|}{ Mean } & \multicolumn{1}{c|}{ Std. Deviation } & Variance \\
\hline VAR00006 & 30 & 58.00 & 91.00 & 75.6000 & 9.17869 & 84.248 \\
Valid N (listwise) & & 30 & & & & \\
\hline
\end{tabular}

Table 2 shows the reliability of the test scores gained from the participants in the PET piloting phase. The Cronbach's alpha formula was employed for this purpose and an acceptable reliability of .936 was obtained.

Table2- Reliability of the PET Piloting Before Deletion of Malfunctioning Items

Table2- Reliability of the PET Piloting Before Deletion of Malfunctioning Items
\begin{tabular}{|c|c|}
\hline Cronbach's Alpha & N of Items \\
\hline .936 & 67 \\
\hline
\end{tabular}

After deletion of the 4 malfunctioning items, the reliability of the test shifted to .976 . Table 3 shows the reliability of the test scores gained after the deletion.

Table 3- Reliability of PET Piloting After Deletion of Four Malfunctioning Items

\begin{tabular}{|c|c|}
\hline Cronbach's Alpha & N of Items \\
\hline .976 & 63 \\
\hline
\end{tabular}

There were two writing tasks in the test rated by two qualified raters (one of the researchers and one of her colleagues) using the predetermined official Cambridge General Mark Schemes for Writing. In order to calculate the inter-rater reliability between the raters, the Pearson Correlation Coefficient was used. The results showed that there was a significant correlation between the two raters (the results are shown in Table 4 and Table 5). 
Table 4- Inter-rater Reliability of the Two Raters in Piloting of Writing Part II

\begin{tabular}{|c|c|c|c|}
\hline & & VAR00001 & VAR00002 \\
\hline \multirow{4}{*}{ VAR00001 } & Pearson Correlation & 1 & $.877^{* *}$ \\
\hline & Sig. (2-tailed) & & .000 \\
\hline & & 30 & 30 \\
\hline & Pearson Correlation & $.877^{* *}$ & 1 \\
\hline \multirow[t]{2}{*}{ VAR00002 } & Sig. (2-tailed) & .000 & \\
\hline & $\mathrm{N}$ & 30 & 30 \\
\hline
\end{tabular}

**. Correlation is significant at the 0.01 level (2-tailed)

Table 5- Inter-rater Reliability of the Two Raters in the Piloting of Writing Part III

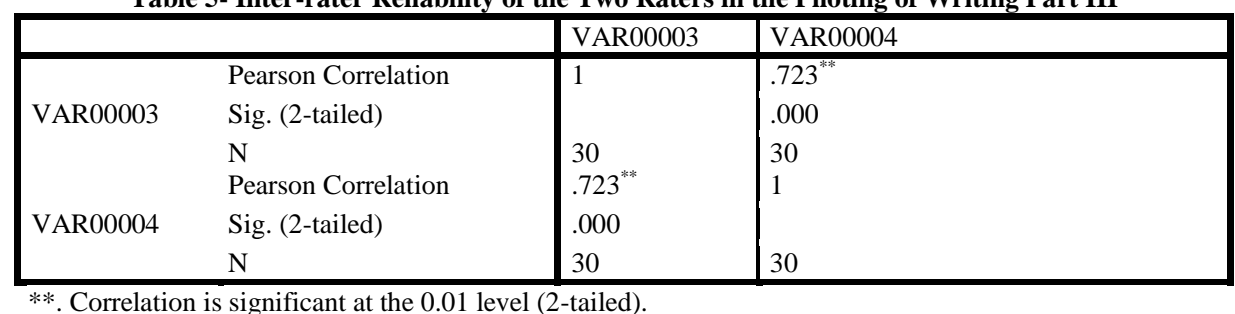

The speaking part of the proficiency test (piloting) was also rated by the same raters using the predetermined official Cambridge General Mark Schemes for speaking.

The researcher also used the Pearson Correlation Coefficient in order to calculate the inter-rater reliability between the two raters. The results showed that there was a significant correlation between the two raters. The results are shown in Table 6.

Table 6- Inter-rater Reliability of the Two Raters in the Piloting of Speaking

\begin{tabular}{|c|c|c|c|}
\hline & & VAR00001 & VAR00002 \\
\hline & Pearson Correlation & 1 & $.778^{* * *}$ \\
\hline VAR00001 & Sig. (2-tailed) & & .000 \\
\hline & $\mathrm{N}$ & 30 & 30 \\
\hline & Pearson Correlation & $.778^{* *}$ & 1 \\
\hline VAR00002 & Sig. (2-tailed) & .000 & \\
\hline & $\mathrm{N}$ & 30 & 30 \\
\hline
\end{tabular}

\section{Descriptive Statistics of the PET Proficiency Test, Administration}

After the procedure of piloting, the PET test was administered to 110 students participated in this study. The descriptive statistics were calculated. Table 7 shows these statistics with the mean of 78.20 and the standard deviation of 7.34 .

Table 7- Descriptive Statistics of the PET, Administration

\begin{tabular}{|l|l|l|l|l|l|}
\hline & $\mathrm{N}$ & Minimum & Maximum & Mean & Std. Deviation \\
\hline VAR00005 & 110 & 58.00 & 91.00 & 78.2091 & 7.34984 \\
Valid N (listwise) & 110 & & & & \\
& & & & & \\
\hline
\end{tabular}

The reliability of the PET in this actual administration for homogenization of the subjects was calculated too (Table 8). An index of .96 reassured the researchers of the reliability of this test.

Table 8- Reliability of the PET, Administration

\begin{tabular}{|c|c|}
\hline Cronbach's Alpha & N of Items \\
\hline .963 & 63 \\
\hline
\end{tabular}

\section{Descriptive Statistics of Reading Comprehension and Writing Ability Pretests, Piloting}

Before starting the treatment, a "Reading Comprehension Pretest" and "Writing Ability Pretest" were administered to know the students' reading comprehension and writing ability before the treatment. These two tests were piloted with 30 students prior to its real administration and the descriptive statistics (Table 9), reliability (Table 10) and inter-rater reliability of the two raters (Table 11) were calculated. 
Table 9- Descriptive Statistics of Reading Comprehension Pretest, Piloting

\begin{tabular}{|l|r|r|r|r|r|r|r|r|r|}
\hline & \multicolumn{1}{|c|}{$\mathrm{N}$} & Range & Minimum & $\begin{array}{c}\text { Maximu } \\
\mathrm{m}\end{array}$ & Mean & Std. Deviation & Variance & \multicolumn{2}{|c|}{ Skewness } \\
\cline { 2 - 9 } & Statistic & Statistic & Statistic & Statistic & Statistic & Statistic & Statistic & Statistic & $\begin{array}{c}\text { Std. } \\
\text { Error }\end{array}$ \\
\hline $\begin{array}{l}\text { VAR00 } \\
\text { O01 } \\
\begin{array}{l}\text { Valid N } \\
\text { (listwise } \\
\text { L }\end{array}\end{array}$ & 30 & 11.00 & 5.00 & 16.00 & 10.9000 & 2.33932 & 5.472 & -.183 & .427 \\
\hline
\end{tabular}

Table 10- Reliability of Reading Comprehension Pretest, Piloting

\begin{tabular}{|c|c|}
\hline Cronbach's Alpha & N of Items \\
\hline .819 & 16 \\
\hline
\end{tabular}

Table 11- Inter-rater Reliability of the two Raters of the Writing pretest, Piloting

\begin{tabular}{|ll|r|r|}
\hline & & VAR00001 \\
\hline \multirow{2}{*}{ VAR00001 } & Pearson Correlation & 1 & $.844^{* *}$ \\
& Sig. (2-tailed) & & .000 \\
& $\mathrm{~N}$ & 30 & 30 \\
& Pearson Correlation & $.844^{* *}$ & 1 \\
VAR00005 & .000 & 30 \\
& Sig. (2-tailed) & 30 & \\
& $\mathrm{~N}$ &
\end{tabular}

\section{Descriptive Statistics of Reading Comprehension and Writing Ability Post-tests, Piloting}

The researcher administered a parallel form of the Reading Comprehension and Writing Ability pretests as post-tests among the experimental and control groups once the treatment was completed. The two tests were thus piloted with 30 students prior to its real administration and the descriptive statistics (Table 12), reliability (Table 13), and inter-rater reliability of the two raters (Table 14) were calculated.

Table 12- Descriptive Statistics of the Reading Comprehension Post-test, Piloting

\begin{tabular}{|c|c|c|c|c|c|c|c|c|c|}
\hline & $\mathrm{N}$ & Range & $\begin{array}{c}\text { Minimu } \\
\mathrm{m}\end{array}$ & $\begin{array}{c}\text { Maximu } \\
\mathrm{m}\end{array}$ & Mean & $\begin{array}{c}\text { Std. } \\
\text { Deviation }\end{array}$ & Variance & \multicolumn{2}{|c|}{ Skewness } \\
\cline { 2 - 9 } & Statistic & Statistic & Statistic & Statistic & Statistic & Statistic & Statistic & Statistic & $\begin{array}{c}\text { Std. } \\
\text { Error }\end{array}$ \\
\hline $\begin{array}{c}\text { VAR0000 } \\
4 \\
\begin{array}{c}\text { Valid N } \\
\text { (listwise) }\end{array}\end{array}$ & 30 & 11.00 & 5.00 & 16.00 & 10.3000 & 2.52095 & 6.355 & -.059 & .427 \\
\hline
\end{tabular}

Table 13- Reliability of the Reading Comprehension Post-test, Piloting

\begin{tabular}{|c|c|}
\hline Cronbach's Alpha & N of Items \\
\hline .833 & 16 \\
\hline
\end{tabular}

Table 14- Inter-rater Reliability of the Two Raters of the Writing Pretest, Piloting

\begin{tabular}{|ll|r|r|}
\hline & & VAR00011 & VAR00012 \\
\hline \multirow{3}{*}{ VAR00011 } & Pearson Correlation & 1 & $.871^{* * *}$ \\
& Sig. (2-tailed) & 30 & .000 \\
& $\mathrm{~N}$ & $.871^{* *}$ & 30 \\
VAR00012 & Pearson Correlation & .000 & 1 \\
& Sig. (2-tailed) & 30 & 30 \\
\hline
\end{tabular}

\section{Checking the Normality}

Before presenting descriptive statistics of the Reading Comprehension \& Writing Ability Pretest administration, it is necessary to provide assumptions for parametric tests.

In order to analyze any sets of data through parametric tests four assumptions should be met; 1) the data should be measured on an interval scale; 2) the subjects should be independent that is to say none of them participates in more than one group, 3) the data should enjoy normal distribution and 4) the groups should have homogeneous variances (Field, 2009). The present data are measured on an interval scale and none of the 
subjects participate in more than one group. The assumption of normality is also met. As displayed in Table 15 the ratios of skewness and kurtosis over their respective standard errors are within the ranges of $+/-2$.

Table 15- Normality Assumptions

\begin{tabular}{|c|c|c|c|c|c|c|c|c|}
\hline \multirow{2}{*}{\multicolumn{2}{|c|}{ GROUP }} & \multirow{3}{*}{$\begin{array}{c}\mathbf{N} \\
\text { Statistic } \\
\mathbf{3 0}\end{array}$} & \multirow{2}{*}{\multicolumn{3}{|c|}{ Skewness }} & \multirow{2}{*}{\multicolumn{3}{|c|}{ Kurtosis }} \\
\hline & & & & & & & & \\
\hline \multirow{4}{*}{ EXPERIMENTAL } & WR PRE & & -1.052 & .427 & -2.46 & 1.465 & .833 & 1.76 \\
\hline & WR POST & 30 & -.624 & .427 & -1.46 & -.832 & .833 & -1.00 \\
\hline & RC PRE & 30 & -.345 & .427 & -0.81 & -.631 & .833 & -0.76 \\
\hline & RC POST & 30 & -.416 & .427 & -0.97 & -.877 & .833 & -1.05 \\
\hline \multirow{4}{*}{ CONTROL } & WR PRE & 30 & -.319 & .427 & -0.75 & -.358 & .833 & -0.43 \\
\hline & WR POST & 30 & -.736 & .427 & -1.72 & -.382 & .833 & -0.46 \\
\hline & RC PRE & 30 & .009 & .427 & 0.02 & -.695 & .833 & -0.83 \\
\hline & RC POST & 30 & -.160 & .427 & -0.37 & .613 & .833 & 0.74 \\
\hline
\end{tabular}

The assumption of homogeneity of variances will be discussed when reporting the results of the independent $t$-test although there is no need to worry about the violation of this assumption because the SPSS produces two lines of report "for situations where the assumption is not violated and for when it is violated" (Pallant, 2005, P. 198).

\section{Descriptive Statistics of the Reading Comprehension \& Writing Ability Pretest, Administration Reading Comprehension Pretest, Administration}

An independent $t$-test is run to compare the experimental and control groups' mean scores on pretest of Reading Comprehension in order to prove that the two groups enjoyed the same level of reading ability prior to the main study. As displayed in Table 16 \& Figure 1 the mean scores for experimental and control groups on Reading Comprehension pretest were 10.07 and 9.93 respectively.

Table 16- Descriptive Statistics of the Pretest of Reading Comprehension of the two groups

\begin{tabular}{|c|c|c|c|c|}
\hline Group & $\mathbf{N}$ & Mean & Std. Deviation & Std. Error Mean \\
\hline EXPERIMENTAL & $\mathbf{3 0}$ & $\mathbf{1 0 . 0 7}$ & $\mathbf{1 . 5 7 4}$ & .287 \\
\hline CONTROL & $\mathbf{3 0}$ & $\mathbf{9 . 9 3}$ & $\mathbf{2 . 2 2 7}$ & .407 \\
\hline
\end{tabular}

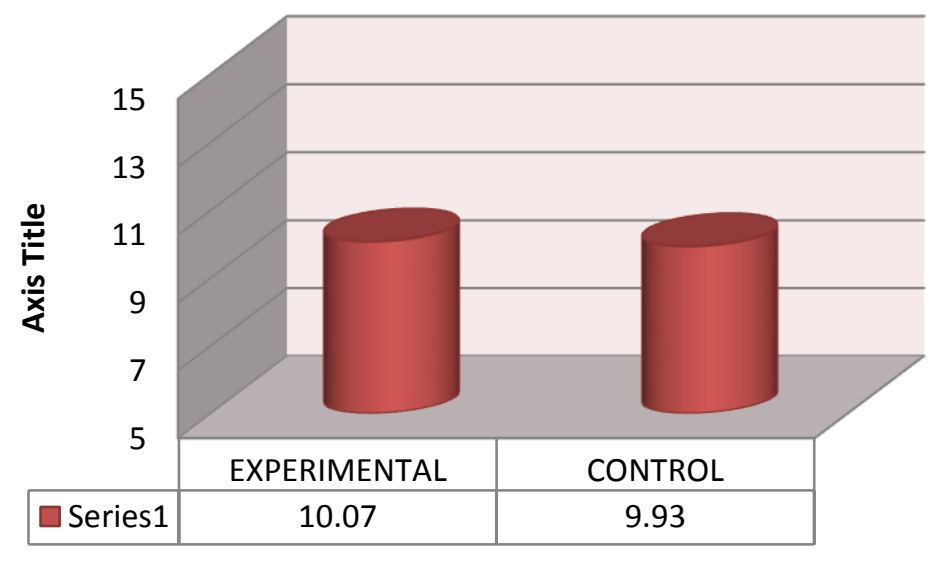

Figure 1- Reading Comprehension Pretest Administration of the Two Groups

The results of the independent $t$-test $[\mathrm{t}(58)=.26, \mathrm{P}=.79>.05 ; \mathrm{R}=.035$ it represents a weak effect size] (Table 17) indicate that there was not any significant difference between experimental and control groups' mean scores on the Reading Comprehension Pretest. Thus, it can be concluded that the two groups enjoyed the same level of reading ability prior to the main study. 
Table 17- Independent t-test of the Reading Comprehension Pretest of the Two Groups

\begin{tabular}{|c|c|c|c|c|c|c|c|c|c|}
\hline & \multicolumn{2}{|c|}{$\begin{array}{c}\text { Levene's Test for } \\
\text { Equality of } \\
\text { Variances } \\
\end{array}$} & \multicolumn{7}{|c|}{ t-test for Equality of Means } \\
\hline & \multirow[t]{2}{*}{$\mathbf{F}$} & \multirow[t]{2}{*}{ Sig. } & \multirow[t]{2}{*}{$\mathbf{T}$} & \multirow[t]{2}{*}{ Df } & \multirow{2}{*}{$\begin{array}{l}\text { Sig. } \\
(2- \\
\text { tailed) }\end{array}$} & \multirow[t]{2}{*}{$\begin{array}{c}\text { Mean } \\
\text { Difference }\end{array}$} & \multirow[t]{2}{*}{$\begin{array}{l}\text { Std. Error } \\
\text { Difference }\end{array}$} & \multicolumn{2}{|c|}{$\begin{array}{l}\text { 95\% Confidence Interva } \\
\text { of the Difference }\end{array}$} \\
\hline & & & & & & & & Lower & Upper \\
\hline $\begin{array}{l}\text { Equal variances } \\
\text { assumed }\end{array}$ & 3.641 & .061 & .268 & 58 & .790 & .133 & .498 & -.863 & 1.130 \\
\hline $\begin{array}{l}\text { Equal variances } \\
\text { not assumed }\end{array}$ & & & .268 & 52.187 & .790 & .133 & .498 & -.866 & 1.132 \\
\hline
\end{tabular}

It should be noted that the assumption of homogeneity of variances is met (Levene's $\mathrm{F}=3.64, \mathrm{P}=.06$ $>$.05). That is why the first row of Table 17, i.e. "Equal variances assumed" is reported.

\section{Writing Ability Pretest, Administration}

An independent $t$-test is run to compare the experimental and control groups' mean scores on Writing Ability Pretest in order to prove that the two groups enjoyed the same level of writing ability prior to the main study. As displayed in Table 18 \& Figure 2 the mean scores for experimental and control groups on Writing Ability Pretest were 14.95 and 14.42 respectively.

Table 18- Descriptive Statistics of the Writing Ability Pretest of the Two Groups

\begin{tabular}{|c|c|c|c|c|}
\hline Group & N & Mean & Std. Deviation & Std. Error Mean \\
\hline EXPERIMENTAL & $\mathbf{3 0}$ & $\mathbf{1 4 . 9 5}$ & $\mathbf{1 . 7 8 3}$ & $\mathbf{3 2 5}$ \\
\hline CONTROL & $\mathbf{3 0}$ & $\mathbf{1 4 . 4 2}$ & $\mathbf{2 . 5 0 2}$ & .457 \\
\hline
\end{tabular}

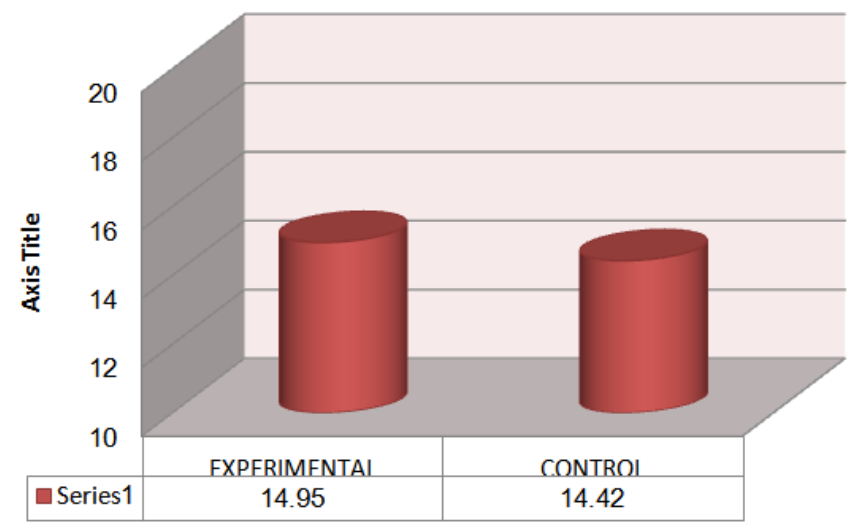

Figure 2- Writing Ability Pretest Administration of the Two Groups

The results of the independent $t$-test $[\mathrm{t}(58)=.95, \mathrm{P}=.34>.05 ; \mathrm{R}=.12$ it represents a weak effect size] (Table 19) indicate that there was not any significant difference between experimental and control groups' mean scores on the Writing Ability Pretest. Thus, it can be concluded that the two groups enjoyed the same level of writing ability prior to the main study.

Table 19- Independent t-test of the Writing Ability Pretest of the Two Groups

\begin{tabular}{|c|c|c|c|c|c|c|c|c|c|}
\hline & \multicolumn{2}{|c|}{$\begin{array}{l}\text { Levene's Test for } \\
\text { Equality of } \\
\text { Variances }\end{array}$} & \multicolumn{7}{|c|}{ t-test for Equality of Means } \\
\hline & \multirow[t]{2}{*}{$\mathbf{F}$} & \multirow[t]{2}{*}{ Sig. } & \multirow[t]{2}{*}{$\mathbf{T}$} & \multirow[t]{2}{*}{ Df } & \multirow[t]{2}{*}{$\begin{array}{l}\text { Sig. (2- } \\
\text { tailed) }\end{array}$} & \multirow[t]{2}{*}{$\begin{array}{c}\text { Mean } \\
\text { Difference }\end{array}$} & \multirow[t]{2}{*}{$\begin{array}{l}\text { Std. Error } \\
\text { Difference }\end{array}$} & \multicolumn{2}{|c|}{$\begin{array}{l}\text { 95\% Confidence } \\
\text { Interval of the } \\
\text { Difference }\end{array}$} \\
\hline & & & & & & & & Lower & Upper \\
\hline $\begin{array}{c}\text { Equal } \\
\text { variances } \\
\text { assumed } \\
\end{array}$ & 2.603 & .112 & .951 & 58 & .346 & .533 & .561 & -.589 & 1.656 \\
\hline $\begin{array}{c}\text { Equal } \\
\text { variances not } \\
\text { assumed }\end{array}$ & & & .951 & 52.413 & .346 & .533 & .561 & -.592 & 1.659 \\
\hline
\end{tabular}


It should be noted that the assumption of homogeneity of variances is met (Levene's $\mathrm{F}=2.60, \mathrm{P}=.11$ $>$.05). That is why the first row of Table 19, i.e. "Equal variances assumed" is reported.

\section{Inter-Rater Reliability of the Writing Ability Pretest, Administration}

The inter-rater reliability for the two raters who rated the students' writings on the pretest administration is $.74(\mathrm{P}=.000<.05)$. These results indicate that there is a significant agreement between the two raters who rated the students' writings on the pretest (Table 20).

\begin{tabular}{|c|c|c|}
\hline & & $\begin{array}{l}\text { Pretest } \\
\text { Rater 2 }\end{array}$ \\
\hline \multirow{3}{*}{$\begin{array}{l}\text { Pretest } \\
\text { Rater } 1\end{array}$} & Pearson Correlation & $.749^{* *}$ \\
\hline & Sig. (2-tailed) & .000 \\
\hline & $\mathbf{N}$ & 60 \\
\hline
\end{tabular}

\section{Descriptive statistics of Reading Comprehension and Writing Ability Post-tests, Administration Reading Comprehension Post-test, Administration}

Table $21 \&$ Figure 3 show the mean scores for experimental and control groups on post-test of Reading Comprehension which were 12.43 and 10.20 respectively.

Table 21- Descriptive Statistics of the Reading Comprehension Post-test of the Two Groups

\begin{tabular}{|l|c|c|c|c|}
\hline Group & $\mathrm{N}$ & Mean & Std. Deviation & Std. Error Mean \\
\hline EXPERIMENTAL & $\mathbf{3 0}$ & $\mathbf{1 2 . 4 3}$ & $\mathbf{2 . 7 1 2}$ & .495 \\
\hline CONTROL & $\mathbf{3 0}$ & $\mathbf{1 0 . 2 0}$ & $\mathbf{2 . 6 3 1}$ & .480 \\
\hline
\end{tabular}

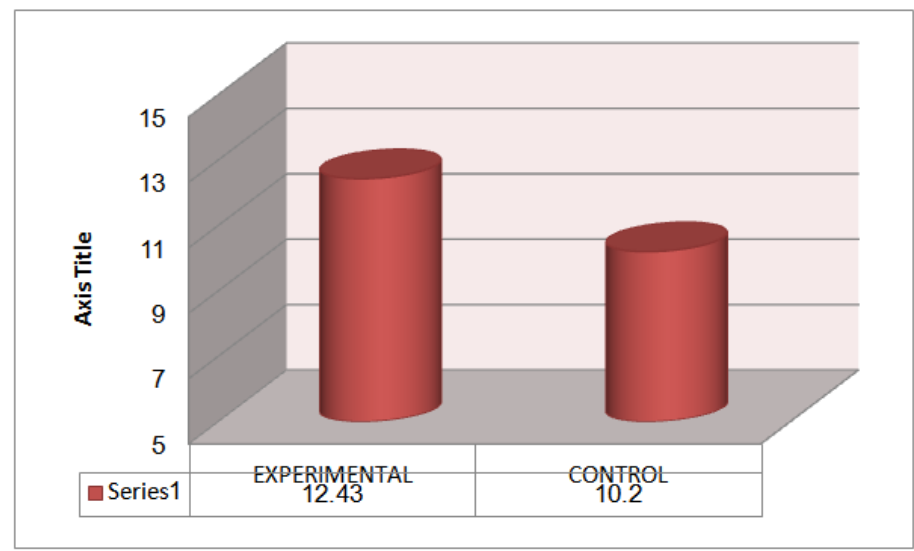

Figure 3- Reading Comprehension Post-test of Two Groups

\section{Writing Ability Post-test, Administration}

As displayed in Table 22 \& Figure 4 the mean scores for experimental and control groups on post-test of writing ability were 17.75 and 15.22 respectively.

Table 22- Descriptive Statistics of Writing ability Post-test of the Two Groups

\begin{tabular}{|l|c|c|c|c|}
\hline Group & $\mathrm{N}$ & Mean & Std. Deviation & Std. Error Mean \\
\hline EXPERIMENTAL & $\mathbf{3 0}$ & $\mathbf{1 7 . 7 5}$ & $\mathbf{1 . 1 1 2}$ & .203 \\
\hline CONTROL & $\mathbf{3 0}$ & $\mathbf{1 5 . 2 2}$ & $\mathbf{2 . 5 6 5}$ & .468 \\
\hline
\end{tabular}




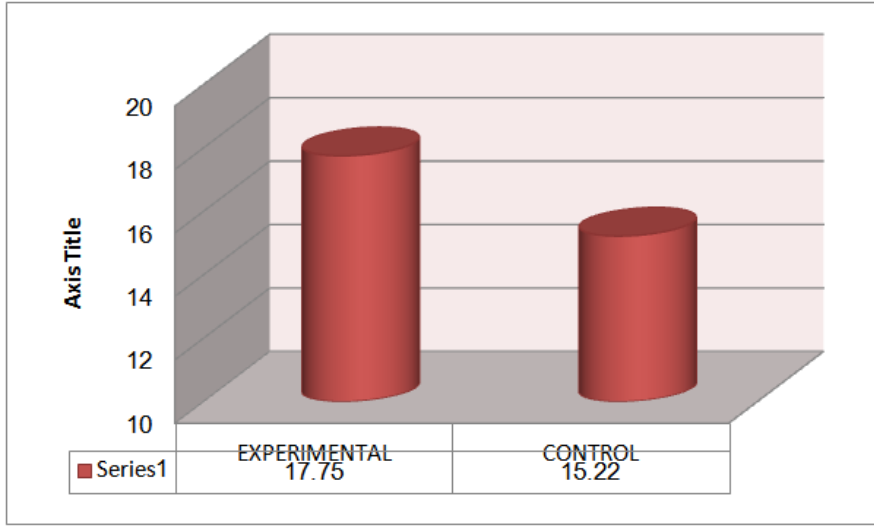

Figure 4- Comparing Means of Writing Ability Post-test of the Two Groups

\section{Inter-Rater Reliability of Writing Ability Post-test, Administration}

The inter-rater reliability for the two raters who rated the students' writings on the post-test is .76 $(\mathrm{P}=$ $.000<.05)$ (Table 23). These results indicate that there is a significant agreement between the two raters who rated the students' writings on the post-test.

Table 23- Inter-Rater Reliability of the Writing Ability Post-test
\begin{tabular}{|l|l|c|}
\hline \multicolumn{2}{|c|}{} & $\begin{array}{c}\text { Posttest } \\
\text { Rater 2 }\end{array}$ \\
\hline \multirow{2}{*}{$\begin{array}{l}\text { Posttest } \\
\text { Rater 1 }\end{array}$} & Pearson Correlation & $.769^{* *}$ \\
\cline { 2 - 3 } & Sig. (2-tailed) & $\mathbf{. 0 0 0}$ \\
\cline { 2 - 3 } & N & $\mathbf{6 0}$ \\
\hline$* *$ Correlation is significant at the 0.01 level (2-tailed). \\
\hline
\end{tabular}

\section{Research Questions}

Following the descriptive statistics of this study, the two research questions were investigated.

\section{Research Question \# 1}

1. Do teaching grammatical consciousness-raising tasks have any statistically significant impact on EFL learners' reading comprehension?

An independent $t$-test is run to compare the experimental and control groups' mean scores on post-test of Reading Comprehension in order to probe the effect of grammatical consciousness-raising tasks on EFL learners' reading comprehension. As displayed in Table 24 the mean scores for experimental and control groups on post-test of Reading Comprehension were 12.43 and 10.20 respectively.

Table 24- Descriptive Statistics of the Reading Comprehension Post-test of Two groups

\begin{tabular}{|l|c|c|c|c|}
\hline Group & $\mathbf{N}$ & Mean & Std. Deviation & Std. Error Mean \\
\hline EXPERIMENTAL & $\mathbf{3 0}$ & $\mathbf{1 2 . 4 3}$ & $\mathbf{2 . 7 1 2}$ & .495 \\
\hline CONTROL & $\mathbf{3 0}$ & $\mathbf{1 0 . 2 0}$ & $\mathbf{2 . 6 3 1}$ & .480 \\
\hline
\end{tabular}

The results of the independent $t$-test $[\mathrm{t}(58)=3.23, \mathrm{P}=.002<.05 ; \mathrm{R}=.39$ it represents a moderate to strong effect size] (Table 25) indicate that there is a significant difference between experimental and control groups' mean scores on the post-test of Reading Comprehension. This means that the experimental group after receiving grammatical consciousness-raising tasks outperformed the control group on the post-test of reading comprehension.

It should be mentioned that the assumption of homogeneity of variances is met (Levene's $\mathrm{F}=.392, \mathrm{P}=$ $.53>.05)$. That is why the first row of Table 25, i.e. "Equal variances assumed" is reported.

Table 25- Independent $t$-test of Reading Comprehension Post-test of the Two Groups

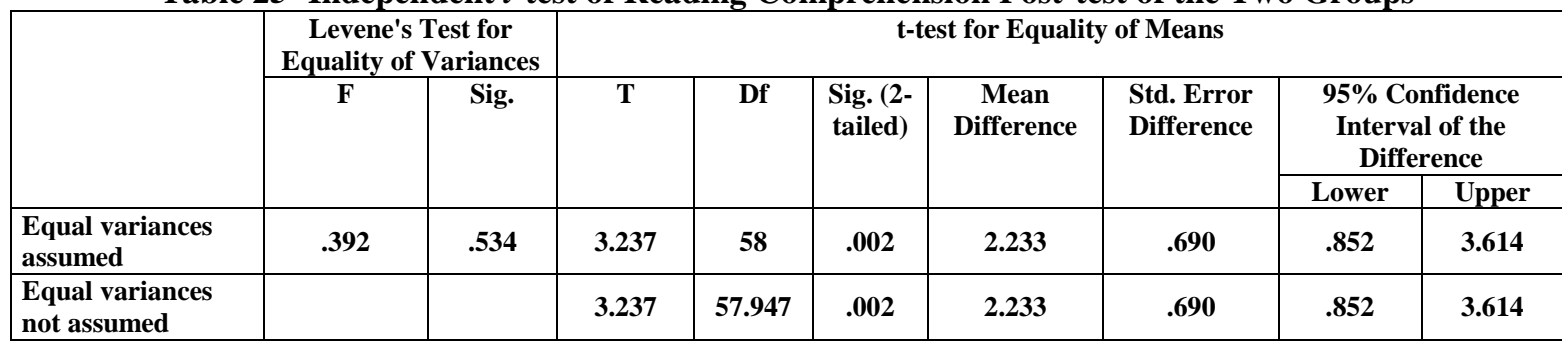




\section{Research Question \# 2}

2. Do teaching grammatical-consciousness raising tasks have any statistically significant impact on EFL learners' writing ability?

An independent $t$-test is run to compare the experimental and control groups' mean scores on post-test of writing ability in order to probe the effect of grammatical consciousness-raising tasks on EFL learners writing ability. As displayed in Table 26 the mean scores for experimental and control groups on post-test of writing ability were 17.75 and 15.22 respectively.

Table 26- Descriptive Statistics of Writing ability Post-test of the Two Groups

\begin{tabular}{|l|c|c|c|c|}
\hline Group & $\mathrm{N}$ & Mean & Std. Deviation & Std. Error Mean \\
\hline EXPERIMENTAL & 30 & 17.75 & 1.112 & .203 \\
\hline CONTROL & 30 & 15.22 & 2.565 & .468 \\
\hline
\end{tabular}

The results of the independent $t$-test $[\mathrm{t}(58)=4.96, \mathrm{P}=.000<.05 ; \mathrm{R}=.62$ it represents a strong effect size] (Table 27) indicate that there is a significant difference between experimental and control groups' mean scores on the post-test of writing. This means that the experimental group after receiving grammatical consciousness-raising tasks outperformed the control group on the post-test of writing.

Table 27- Independent $t$-test of the Writing Ability Post-test of the Two Groups

\begin{tabular}{|c|c|c|c|c|c|c|c|c|c|}
\hline & \multicolumn{2}{|c|}{$\begin{array}{c}\text { Levene's Test for } \\
\text { Equality of Variances }\end{array}$} & \multicolumn{7}{|c|}{ t-test for Equality of Means } \\
\hline & \multirow[t]{2}{*}{$\mathrm{F}$} & \multirow[t]{2}{*}{ Sig. } & \multirow[t]{2}{*}{$\mathrm{T}$} & \multirow[t]{2}{*}{$\overline{\mathrm{Df}}$} & \multirow[t]{2}{*}{$\begin{array}{l}\text { Sig. (2- } \\
\text { tailed) }\end{array}$} & \multirow[t]{2}{*}{$\begin{array}{c}\text { Mean } \\
\text { Difference }\end{array}$} & \multirow[t]{2}{*}{$\begin{array}{l}\text { Std. Error } \\
\text { Difference }\end{array}$} & \multicolumn{2}{|c|}{$\begin{array}{l}\text { 95\% Confidence } \\
\text { Interval of the } \\
\text { Difference }\end{array}$} \\
\hline & & & & & & & & Lower & Upper \\
\hline $\begin{array}{l}\text { Equal variances } \\
\text { assumed }\end{array}$ & 20.898 & .000 & 4.963 & 58 & .000 & 2.533 & .510 & 1.511 & 3.555 \\
\hline $\begin{array}{l}\text { Equal variances } \\
\text { not assumed }\end{array}$ & & & 4.963 & 39.531 & .000 & 2.533 & .510 & 1.501 & 3.565 \\
\hline
\end{tabular}

\section{Discussion And Conclusion}

There has been a controversy among different linguists and researchers that whether teachers should teach grammar or not; and also how teachers should teach grammar in the classroom (Amirian and Sadeghi, 2012). Some linguists such as Krashen (1982) believed that formal instruction in grammar would not lead to the acquisition of knowledge. Prabhu (1987) also argued that by practicing in meaning-focused tasks, learners can acquire L2 grammar naturalistically.

According to Crivos and Luchini (2012), "An effective grammar teaching model should be compatible with a communicative framework that emphasizes learners' understanding of classroom input through meaningful, negotiated interactions" (p. 149). Such a model should integrate explicit grammar instruction with communicative language teaching. It should aim at helping students become aware of how grammatical features work. This awareness can facilitate and trigger learning and help students in the process of becoming active participants and less dependent on teachers. Learning a language, and hence its grammar, is a lifetime commitment and the contact between teacher and learner is just a short phase in this undertaking. Therefore, it is essential to give learners the means and motivation to take part in their own learning processes. Grammar consciousness-raising tasks combine the development of knowledge about problematic L2 grammatical features with the provision for meaning-focused use of the target language.

Consciousness-Raising (CR) Tasks enable learners to develop explicit knowledge of grammar. It does not involve the learner in repeated production. This is because the purpose of this kind of grammar teaching is not to help learners to perform structures correctly but to help them to gain some knowledge about it.

CR constitutes an approach to grammar teaching which is compatible with current thinking about how learners acquire L2 grammar. It also constitutes an approach that accords with progressive views about education as a process of discovery through problem-solving tasks (Rezaei \& Hosseinpur, 2011).

The present study is an attempt to investigate the effect of grammar consciousness-raising tasks on Iranian EFL learners' reading comprehension and writing ability. The statistical analysis of the data revealed that the improvement occurred in the reading comprehension and writing ability of the participants of experimental group, in comparison to their previous stage, was due to the introduction of a specific variable which was the technique of grammar consciousness-raising tasks. That is to say, teaching grammatical points through grammar consciousness-raising tasks significantly increased learners' reading comprehension and writing performance.

Moreover, comparison of the data obtained from experimental group on reading and writing post-tests also revealed that grammatical consciousness-raising tasks have more impact on Iranian EFL learners' writing than on their reading comprehension. In other words, the experimental group after receiving the grammatical consciousness-raising tasks was more conscious of the target grammar features and used them correctly and as a result performed better on the post-test of writing. 
Although, this study was limited in duration and scope the results clearly supports earlier research on consciousness-raising tasks in the domain of reading comprehension and writing which found that it has a positive effect on reading comprehension and writing performance of learners and also establishes enjoyable class time period and group work while learning grammar points (Fotos, Fotos and Ellis, Mohamed, as cited in Ellis, 2003).

However, it should also be noted that there are some limitations to consciousness-raising. Yip (1994) and Ellis (2002) argue that participation and performance of learners is highly correlated with their interest. Those who are interested in these tasks or the features under study pay more attention to the input and internalize them more easily.

\section{References}

[1] Abbasian Boroujeni, F. (2012). Investigating controversies in teaching grammar: A case for the Iranian high school students. Theory and Practice in Language Studies, 2(8), 1570-1575.

[2] Amirian, M. \& Sadeghi, F (2012). The effect of grammar consciousness-raising tasks on EFL learners performance. International Journal of Linguistics, 4 (3), 708-720.

[3] Behrouzi, P., \& Kazemirad, F. (2012). The effect of consciousness-raising tasks on Iranian elementary EFL learners' syntax acquisition. International Journal of Linguistics 4(2), 334-347.

[4] Chin, B. A. (2000). The role of grammar in improving student's writing. Retrieved October 23, 2012 from: http://www.uwplatt.edu/ ciesield/graminwriting.htm

[5] Crivos, M. B., \& Luchini, P. L. (2012). A pedagogical proposal for teaching grammar using consciousness-raising tasks. MJAL, 4(3), 141153.

[6] Cushing Weigle, S. (2002). Assessing writing. Cambridge: Cambridge University Press.

[7] Ellis, R. (2002). Grammar teaching-practice or consciousness. In J. C. Richards, \& W. A. Renandya, Methodology in Language Teaching: An Anthology of Current Practice (pp. 167-174). NewYork: Cambridge University Press.

[8] Ellis, R. (2003). Task-based language learning. Oxford: Oxford University Press.

[9] Ellis, R. (2005). Instructed second language acquisition: A literature reveiw. New Zealand: Research Division, Ministry of Education. Retreived September $\quad 12, \quad 2012 \quad$ from: http://www.hum.uu.nl/medewerkers/h.vandenbergh/Language\%20Education/Artikelen/Ellis_2005_instructed-second-language.pdf

[10] Feild, A. (2009). Dicovering statistics using SPSS. London: Sage Publications.

[11] Fotos, S. (1994). Integrating grammar instruction and communicative language use through grammar consciousness-raising tasks. TESOL QUARTERLY, 28(2), 323-351.

[12] Grabe, W. (2008). Reading in second language: Moving from theory to practice. NewYork: Cambridge University Press. Retreived October 12, 2012 from: http://books.google.com/books/about/Reading_in_a_Second_Language.html?id=prvRHZ7DrIcC

[13] Hedge, T. (2003). Teaching and learning in language classroom. Oxford: Oxford University Press.

[14] Kintsch, W. (1988). The role of knowledge in discourse comprehension: A construction-integration model. Psychological Review, 92, 163182.

[15] Kintsch, W., \& Van Dijk. (1978). Toward a model of text comprehension and production. Psychological Review, 85, $363-394$.

[16] Koda, K. (2007). Reading and language learning: Crosslinguistic constraints on second language reading development. Language Learning, $5,1-44$.

[17] Krashen, S. D. (1982). Second language acquisition and second language learning. London: Longman.

[18] Lopez, A. L. (2008). To what extent does grammar kwnoledge account for competence in FL reading comprehension in university students? RESLA 21, 181-200.

[19] McCarthy, M., McCarten, J., \& Sandiford, H. (2005). Touch Stone 2: Teaccher's edition. Cambridge: Cambridge University Press.

[20] Nitta, R., \& Gardner, S. (2009). Form-focused tasks in ELT coursebooks: A framework for analysis. 19-49. Retreived September 12, 2012 from: www2.ngu.ac.jp/uri/gengo/pdf/genbun_vol2101_03.pdf

[21] Pallant, J. (2005). SPSS survival manual. Astrualia: Open University Press.

[22] Prabhu, N. S. (1987). Second language pedagogy. Oxford: Oxford University Press.

[23] Rezaei, A. A., \& Hosseinpur, R. M. (2011). On the role of consciousness-raising tasks in learning grammar: A learner perspective. Iranian EFL Journal, 7(4), 237-254.

[24] Richards, J. C., \& Schmidt, R. (2002). Longman dictionary of language teaching and linguistics (3 ${ }^{\text {rd }}$ ed.). Malaysia: Pearson Education.

[25] Riyad Sharaf, S. (2011). The effect of teaching grammar in writing contexts to enhance using grammar functionally for eleventh graders in Gaza governorate. Unpublished master`s thesis. Retreived October 17, 2012 from: http://ntdc.alazhar.edu.ps/upload/e_thesis/samah.pdf

[26] Rodríguez, A. G. (2009). Teaching grammar to adult English language learners: Center for applied linguistics. Retreived September 27,2012 from: www.cal.org/caelanetwork/pdfs/TeachingGrammarFinalWeb.pdf

[27] Sharil, W. N. (2009). Taking charge of learning: Producing accuracy in writing. $2^{\text {nd }}$ International Conference of Teaching and Learning. pp. 1-4. Malaysia: University Teknologi MARA. Retreived September 25, 2012 from: https://my.laureate.net/Faculty/docs/Faculty\%20Documents/INTI\%20Conferences/Parallel\%20Sessions\%202/2A/2A-05P93\%20\%28Malaysia\%29.pdf

[28] Shiotsu, T. (2009). Reading ability and components of word recognition speed: The case of L1-Japanese EFL learners. In Z. H. Han \& N. J. Anderson (Eds.), Second language reading research and instruction: Crossing the boundaries (pp. 15-39). Michigan: The University of Michigan Press.

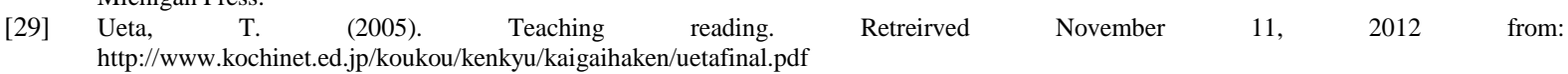

[30] Walsh, M. (2005). Consciousness-raising (C-R): Its background and application. Retreived October 14, 2012 from: www.walshsensei.org/Walsh2005CR.pdf

[31] Weisi, H. (2012). Is reading comprehension of ESP program improved by explicit teaching of grammar? The Journal of Teaching Language Skills (JTLS, 3(4), 145-158.

[32] Willis, D., \& Willis, J. (1996). Consciousness-raising activities. Retreived October 18, 2012 from: www.williselt.co.uk/downloads/focusonmeaning.doc

[33] Yip, V. (1994). Grammatical consciousness-raising and learnability. In T. Odlin (Ed.), Perspectives on pedagogical grammar (pp. 123-139). Cambridge: Cambridge University Press. 